\title{
Open Data Potential in the Realm of Urban Planning
}

\section{Potenciál využití otevřených dat v městském plánování}

Eva Horáková, xahorakovae@stud.fa.vutbr.cz

Ústav prostorové tvorby, Fakulta architektury, Vysoké učení technické v Brně školitel: doc. Ing. arch. Jiř́i Palacký, Ph.D.

\begin{abstract}
Open data are collected by public institutions and freely distributed online in computer readible format. This enable third parties to further use data for various appllications or participatory processes in the city. Which cities had already joined the open data concept and what kind of information they mostly open? This paper brings an overview to open data situation in Czech and Slovak cities.
\end{abstract}

KEYWORDS: urban planning; Smart cities; open data; life quality; public space

\begin{abstract}
ABSTRAKT: Otevřená data jsou data sbíraná veřejnými institucemi, která jsou volně dostupná na internetu a distribuována $\mathrm{v}$ počítačově čitelném formátu. To umožňuje a zjednodušuje jejich další využití třetími stranami. Tato veřejná data je možné dále zpracovávat pro nejrůznější aplikace zjednodušující veřejnou participaci a orientaci ve městě. Jaká města se již k otevřeným datům připojila a která data nejčastěji otvírají? Tento př́spěvek podá přehled o situaci stavu využívání otevřených dat u českých a slovenských měst.
\end{abstract}

KLÍČOVÁ SLOVA: územní plánování; Smart cities; otevřená data; kvalita života; veřejný prostor 


\section{Úvod}

Velkým potenciálem dnešních měst se stává stále širší využívání moderních technologií. Technika zasahuje do našich životů čím dál více. Začíná to mobilním telefonem a pokračuje používáním počítačů téměř ve všech pracovních odvětvích a samostatně činných městských online aplikací informujících nás například o čase prúítího blokového čištění. Spousta měst se snaží stát se chytrými městy (Smart Cities). „Tato města jsou společenství lidí komunikující a používající toky energie, materiálů, služeb a financování s cílem urychlit udržitelný hospodářský rozvoj, stabilitu a vysokou kvalitu života; tyto toky a interakce se stávají chytrými, a to prostřednictvím strategického využivání informačních a komunikačních infrastruktur a služeb v procesu transparentniho územního plánování a řízení, které je citlivé vůči sociálním a ekonomickým potřebám společnosti“ (Bárta, 2014).

Chytrá města by však neměla stát pouze na technologiích a jejich rozmístění všude po městě, nýbrž na efektivních strategiích a jejich adaptabilitě. Jedním ze způsobů aplikace tohoto př́istupu a přiblížení se konceptu moderního města je využívání otevřených dat Tento prríspěvek se věnuje publikaci otevřených dat např́ič českými městy a několika zahraničními př́klady.

\section{Otevřená data}

Otevřená data jsou oficiální pojem. Nakládání s nimi a jejich zveřejňování nově upravuje česká legislativa novelou zákona č. 106/1999 Sb., o svobodném přístupu $\mathrm{k}$ informacím, s účinností od 1. 1. 2017. Ta také definuje pojem otevřená data (zákon č. 106/1999 Sb., o svobodném přístupu k informacím). „Otevřená data jsou informace a čísla bezplatně a volně dostupná na internetu ve strukturované a strojově čitelné podobě a jsou zpř́stupněna zpi̊sobem, který jejich využití neklade zbytečné technické či jiné překážky. Formát a struktura otevřených dat tedy umožňují jejich hromadné počítačové zpracování, kněmuž jejich vydavatel poskytl právní svolení. Díky tomu mohou být dál volně zpracovávána, a to i v rámci softwarových aplikací. Jedná se napríklad o jízdní ŕády, př́imy států, seznam poskytovatelů sociálních služeb, kalendár ministra nebo měření čistoty ovzduší. “Tyto informace pocházejí mimo veřejnou správu i z univerzit, nevládních organizací nebo soukromých firem (Otevřená data, 2017).

\section{Výhody otevřených dat}

Velkou výhodou otevřených dat je, že jsou to ve velké většině data, která již existují. Jejich sběr probíhá kontinuálně, bud' jako hlavní, nebo i jako vedlejší produkt. Pocházejí-li z veřejných institucí, jsou tyto informace placeny z daní poplatníků. V př́padě, 
že pocházejí z jiných zdrojů, jsou placeny uživateli nebo jsou to data nezbytná pro chod určité služby, např́klad data mobilních operátorů. To znamená, že by měla být otevřena a zveřejněna, nebot není potřeba je sbírat a platit znovu.

Díky otevřeným datům lze zlepšit transparentnost služeb a zajistit lepší informovanost obyvatel.

Data mají velký ekonomický potenciál. Jedním z př́ikladů aplikací fungujících na otevřených datech je idos - přehled jízdních řádů. Tato aplikace využívá zveřejněné jízdní řády, které může porovnávat díky tomu, že jsou ve stejném formátu. Stojí na veřejných datech, společností je soukromý subjekt, poskytující veřejnou službu, kdy celý provoz aplikace je financován z reklamy na webu. Služba šla tak daleko, že nyní je schopna sledovat vozy v reálném čase a podávat uživateli informace o aktuálním zpoždění vyhledaného spoje, čímž je celá služba v Evropě jedinečná (Bárta, 2014).

Otevřená data lze dále využívat k zefektivňování veřejné správy a jejího fungování $\mathrm{v}$ reálném čase a hlavně $\mathrm{v}$ součinnosti s obyvateli měst a země. $\mathrm{V}$ této části využívání dat vidíme velký přínos i pro územní plánování a efektivní komunikaci mezi městem a jeho obyvateli o územním plánu a strategiích.

\section{Problémy otevřených dat}

Dat a jejich otevřenosti se samozřejmě dotýká i možnost určitých rizik. Jedním z nich může být např́íklad narušení soukromí. V pojmu otevřená data je definováno, že mezi tato data patři pouze ta, která byla anonymizována, př́padně abstrahována, aby nebylo narušeno ničí soukromí. Dalším možným problémem, který se váže $\mathrm{k}$ práci s daty, je obsahová rozdílnost dat zveřejňovaných jednotlivými městy. $\mathrm{V}$ tomto směru neexistuje žádná standardizace otevřených dat, takže reálně mezi sebou stejná data zatím moc nelze porovnávat.

Data by správně také měla obsahovat metadata - informace o tom, jak byla pořízena a čeho přesně se týkají. Vypovídací hodnota dat a jejich správná interpretace je klíčová pro komunikaci mezi městem a jeho obyvateli.

Posledním problémem otevřených dat by mohla být bezpečnost informací. Je pravda, že otevřená data zveřejňují údaje o městu, o státu, o obyvatelích. Ve většině případů se však nejedná o nové nebo nedostupné informace. Tyto informace již dávno existují, může si je vyhledat každý, kdo o ně má zájem. Po otevření to sice bude mít jednodušší, výhody a možnosti využití dat ale převažují. 


\section{Srovnání otevřenosti měst}

Článek srovnává žebříčky otevřenosti měst v České a Slovenské republice z roku 2016 zpracované na webu cityone.cz. Ten k hodnocení využívá Metodiku Konceptu inteligentních měst Ministerstva pro místní rozvoj (Sirotek, Židková, 2017). Tato metodika definuje cíle a aspekty konceptu inteligentních měst (Smart Cities). V rámci metodiky je popsána i míra otevřenosti dat hodnocená jednou až pěti hvězdami:

* data zveřejněná online - uzavřené, ale zveřejněné formáty, např́íklad naskenované pdf

** strojově čitelná data - základní otevřené formáty, splňují požadavky dle zákona č. 106/1999 Sb., o svobodném prŕístupu k informacím (1)

*** otevřená data - standard pro data veřejné správy/samosprávy

**** univerzální indikátory - datové informace pochopitelné pro člověka i počítač, $\mathrm{v}$ českém prostředí se momentálně jedná o nadstandardní formát

***** propojená data - takový formát, který umožňuje strojově abstrahovat data $\mathrm{z}$ více tabulek a smysluplně je poskládat dohromady

Tato metodika poskytuje měřitelnost otevřenosti města definovanou bodově hodnocenými indikátory. Pomocí nich lze posoudit otevřenost dat města z hlediska kvantity a kvality i výsledného použití (Metodika Konceptu inteligentních měst, 2015).

\section{Situace v České republice}

V České republice se liší situace v jednotlivých městech. Na základě informací z webu cityone, který otevřenost měst dlouhodobě sleduje, se $\mathrm{k}$ otevřeným datům připojilo v ČR 26 statutárních měst.

Mezi českými městy v otevřenosti suverénně vede hlavní město Praha, druhá je Plzeň, třetí Hradec Králové, čtvrtá Ostrava a pětici uzavírá Brno. Mezi města s nejlépe obsahově strukturovanými daty se řadí Plzeň, která data zveřejnila na platformě open source (Zimmerman, 2017).

Města nejčastěji zveřejňují informace o svých mapách a katastrech, dále o odpadovém hospodářství, zeleni a sportovištích. Často zveřejňovanými otevřenými daty jsou také ta o veřejné dopravě, parkování a cenových mapách. Už méně jsou napřríč městy 
zveřejňována data o zdravotnictví, hřbitovech nebo veřejně prospěšných stavbách.

\section{Situace na Slovensku}

$\mathrm{Na}$ Slovensku zkoumala společnost Clevermaps otevřenost 28 statutárních měst. Oproti Praze, která v českém výzkumu v žebříčku vedla, se Bratislava umístila až na 19. místě. Nejlépe hodnoceným městem roku 2016 byl Prešov, následovaly Levice, Nitra, Žilina a pětici uzavřely Pieštany (Zimmerman, Bárta, 2017).

Mezi nejčastěji sbíraná data patří seznamy objednávek, smluv a faktur, jejichž zveřejňování je na Slovensku povinné. Za nimi následují demografické informace, seznamy ulic města a seznamy daňových dlužníků. Ty zveřejňují všechna města, byt i v neotevřeném formátu.

Z mapových informací města nejčastěji zveřejňují informace o katastru, uliční síti a školství.

\section{Závěrečné srovnání - zhodnocení}

Otevírání veřejných dat a jejich další využívání v sobě nesou velký potenciál. V rámci srovnání České republiky a Slovenska je situace v obou zemích obdobná. Každá země má jedno město, které suverénně technologicky vede, ČR Plzeň, SR Prešov, a ostatní města si zatím drží odstup. Oproti Praze se značným počtem datových sad v čele českého žebříčku se však Bratislava propadá a v oblasti otevřených dat příliš nedrží krok.

Slovenská města jsou ve sběru dat oproti českým jednotnější, sbírají podobná data a díky asi třem typům dodavatelů systémů elektronické evidence je po nalezení portálů orientace $\mathrm{v}$ nich celkem přehledná. U měst obou států vedou mezi zveřejňovanými daty data o katastru nemovitostí a volebních okrscích. V případě hledání informací na webech jednotlivých měst obou zemí je však orientace stále celkem nepřehledná. Budoucnost otevírání dat vidíme v určité standardizaci, určení, jaké informace otevírat a jak. Dále v předávání zkušeností z měst, kde se daří data otevírat úspěšněji, jako právě v Plzni, Praze a Prešově, těm městům, která svá data zatím zveřejňují minimálně. Při standardizovaném otevírání dat se podaří docílit velké míry transparentnosti a objektivního statistického srovnání měst. Vyšší standard a srovnatelnost dat napříč městy se pozitivně odrazí i v možnostech využití těchto dat k územnímu plánování především v oblastech dopravy, tepelné pohody a komunikace mezi městem a jeho obyvateli nejen při tvorbě územních plánů.

Příspěvek vznikl ve vazbě na výzkumný projekt GA ČR 17-26104S Vliv charakteru a umístění urbanistické struktury na udržitelný rozvoj území. 


\section{ŽEBŘíČEK OTEVŘENOSTI ČESKÝCH MĚST 2017}

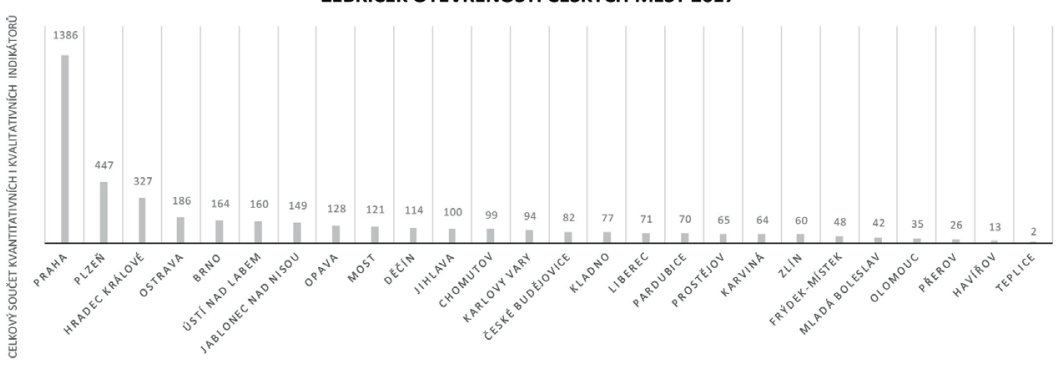

Obr. 1. Otevř̀nost měst v České republice (archiv autora)

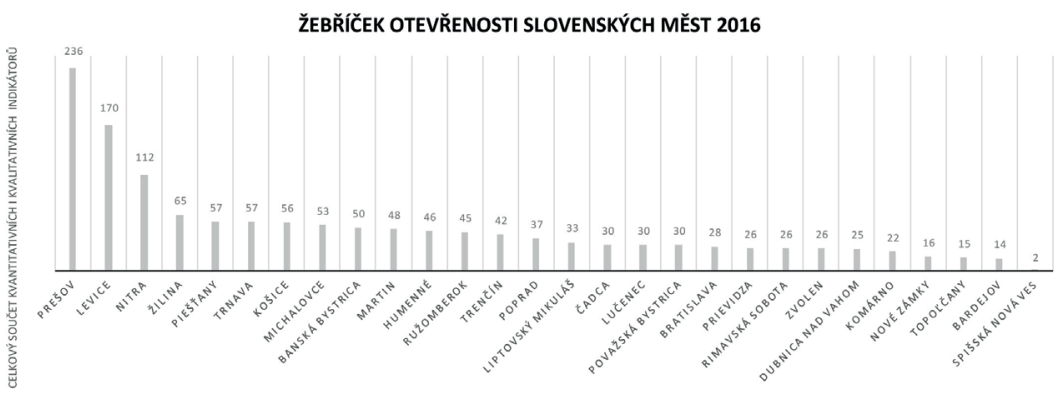

Obr. 2. Otevřenost měst na Slovensku (archiv autora) 


\section{Prameny}

BÁRTA, David, 2014. Open data ve Vídni. Smart cities: magazín o chytrých technologiích pro efektivnější správu měst a obcí. Brno: Ondřej Doležal - Pixl-e, 2014(01), 19-21. ISSN 2336-1786.

Zákon č. 106/1999 Sb. o svobodném přístupu k informacím, ve znění pozdějších předpisů

Otevřená data, 2017. Otevřená data: Společně otvíráme data [online]. Praha: Fond Otakara Motejla [cit. 2017-08-27]. Dostupné z: http://www.otevrenadata.cz/otevrena-data/

BÁRTA, David, 2014. Informační dopravní systém versus otevřená data. Smart cities: Magazín o chytrých technologiích pro efektivnější správu měst a obcí. Brno: Ondřej Doležal - Pixl-e, 2014(01), 28-33. ISSN 2336-1786

SIROTEK, Jan a Šárka ŽIDKOVÁ, 2017. Žebříček oteevřených dat 2016. In: City:one.: Tržiště chytrých řešení pro města [online]. Brno: CityOne [cit. 2017-08-26]. Dostupné z: https://www.cityone.cz/en/zebricek-otevrenych-dat-2016/t6504

ČESKÁ REPUBLIKA, Metodika Konceptu inteligentních měst: Projekt TB930MMR001, 2015. In: . Brno: Ministerstvo pro místní rozvoj. Dostupné také z: http://www.strukturalni-fondy.cz/getmedia/9c597c78-8651-43a8-8d94-bc9f19da74c5/TB930MMR001_Metodika-konceptu-Inteligentnich-mest-2015.pdf

ZIMMERMAN, Michal, 2017. Žebříček datové otevřenosti českých statutárních měst v roce 2017. In: City:one.: Tržiště chytrých řešení pro města [online]. Brno: CityOne [cit. 2017-07-11]. Dostupné z: https://www.cityone.cz/zebricek-datove-otevrenosti-ceskych-statutarnich/t6680

ZIMMERMAN, Michal a David BÁRTA, 2017. Představujeme žebřiček otevřenosti slovenských měst 2016. In: City:one.: Tržiště chytrých řešení pro města [online]. Brno: CityOne [cit. 2017-08-25]. Dostupné z: https://www.cityone.cz/en/predstavujeme-zebricek-otevrenosti-slovenskych/t6596 